\title{
A meta-analysis of the prevalence of African animal trypanosomiasis in Nigeria from 1960 to 2017
}

\author{
Paul Olalekan Odeniran ${ }^{1,2}$ and Isaiah Oluwafemi Ademola ${ }^{1 *}$
}

\begin{abstract}
Background: African animal trypanosomiasis is an economically significant disease that affects the livestock industry in Nigeria. It is caused by several parasites of the genus Trypanosoma. National estimates of the disease prevalence in livestock and tsetse flies are lacking, therefore a systematic review and meta-analysis were performed to understand the trend of the disease prevalence over the years.

Methods: Publications were screened in Web of Science, Ovid MEDLINE, Global Health, EMBASE and PubMed databases. Using four-stage (identification, screening, eligibility and inclusion) process in the PRIMSA checklist, only studies that met the inclusion criteria for AAT and tsetse infections were analysed. Point estimates prevalence and subgroup analyses based on diagnostic techniques in livestock were evaluated at 95\% confidence interval (Cl).

Results: A total of 74 eligible studies published between 1960 and 2017 were selected for meta-analysis. This covers the six geopolitical zones, involving a total of 53,924 animals. The overall prevalence of AAT was 16.1\% (95\% Cl: 12.3-20.3\%). Based on diagnostic techniques, the prevalence of AAT in cattle was highest in PCR followed by serology and microscopy while the highest prevalence in pigs was observed with serology. Out of 12,552 tsetse flies examined from 14 eligible studies, an overall prevalence of $17.3 \%$ (95\% Cl: 4.5-36.0\%) and subgroup prevalence of 49.7\% (95\% Cl: 30.7-68.8\%), 11. 5\% (95\% Cl: $6.1-18.5)$ and $4.5 \%(95 \%$ Cl: 1.8-8.8\%) in G. morsitans, G. tachinoides and G. palpalis, respectively, were observed using the random effects-model.

Conclusions: The prevalence of trypanosomes in both vectors and animal hosts was high in Nigeria. Therefore, further research on risk factors, seasonal and transhumance effects, vectoral capacity and competence are warranted for an effective control of AAT in Nigeria.
\end{abstract}

Keywords: Prevalence, Trypanosomes, Livestock, Tsetse, Nigeria

\section{Background}

African animal trypanosomiasis (AAT) is caused by extracellular protozoan parasites of the genus Trypanosoma and it severely affects the livestock industry in Nigeria causing significant losses which ranges from a decrease in milk production to death [1]. The wide distribution of the disease is attributed to the abundance of its biological and mechanical transmitting vectors which are tsetse flies and biting flies, respectively [2]. All warm-blooded animals including wildlife species have been implicated in the

\footnotetext{
* Correspondence: io.ademola@ui.edu.ng

'Department of Veterinary Parasitology, Faculty of Veterinary Medicine,

University of Ibadan, Ibadan, Nigeria

Full list of author information is available at the end of the article
}

transmission cycle of the disease [3]. The mature infective form of the parasite, metacyclic trypomastigote, is found in the invertebrate host where several reproductive and developmental stages takes place [4]. Trypanosomes evade the immune system of the host because it possesses a variable surface antigen (VSG) which prevents them from lysing by complement alternative pathway $[5,6]$.

Tsetse flies cover an approximately $80 \%$ of the landmass in Nigeria [7], hence AAT continues to thrive, and losses incurred have not reduced [8]. The prevalence of trypanosome infections in the tsetse flies is often neglected probably due to the intensive labour required for its evaluation $[9,10]$. Dissection of tsetse flies remains the most common technique for detecting trypanosomes. However, 
serological and molecular techniques were assumed to detect higher levels of infection and genetic diversity [10, 11]. Diagnosis of AAT in Nigeria has relied on microscopy for decades [12], although the technique is not very sensitive $[13,14]$. Hence, low prevalence reporting at a time was due to diagnostic technique used. Only a few studies in recent years have been reported using serology and PCR [11, 14-17].

At present, there are no national AAT and tsetse infection prevalence rates in Nigeria but there are lots of regional disjointed AAT data sets that ought to be amalgamated to provide a national AAT and tsetse trypanosome infection rate. The effort of the Pan African Tsetse and Trypanosomiasis Eradication Campaign (PATTEC-Nigeria) seems not to be felt across the country [18], because there is no concise information on the trend of the disease in various livestock. To the authors' knowledge, there is no study which has addressed the overall prevalence of Trypanosoma species infection in livestock and the risk associated with these infections in Nigeria. Therefore, this systematic review and meta-analysis was performed to determine the prevalence of Trypanosoma spp. in relation to diagnostic techniques used in livestock. The purpose was to provide data sets that are important in assessing the success of AAT control programmes over time, particularly with the increasing demand on improving food security in an ever-increasing human population.

\section{Methods}

This study was conducted in accordance with the PRISMA guidelines (Preferred Reporting Items for Systematic Reviews and Meta-Analyses) which was used to ensure inclusion of all relevant information in the analysis [19] (see Additional file 1: Table S1).

\section{Search strategy}

Publications were screened in Web of Science, Ovid MEDLINE, Global Health, EMBASE and PubMed using the University of Edinburgh Library database. The last search was done on the 7th September 2017. Search terms were done in English and included: trypanosomes, bovine, small ruminant, porcine, horses, camels, tsetse, Glossina, trypanosomiasis and Nigeria. Reference lists of relevant articles were visually scanned through to locate any omitted study.

\section{Inclusion criteria}

A total of 781 published articles on AAT and tsetse infections were retrieved from the databases and reference lists of relevant studies assessed (Fig. 1). A total of 197 and 19 full texts on AAT and tsetse infections, respectively, were considered for eligibility screening (Fig. 1) after reading and sorting in Zotero Standalone (version 3.0.11). Inclusion criteria for meta-analysis were based on the following details: study type, location of study, tsetse species prevalence, Trypanosoma species prevalence, overall prevalence of trypanosomiasis in sampled herd, number of animal/tsetse examined, method of diagnosis and year of sampling. After assessing eligible studies, 74 and 14 studies representing AAT and tsetse infections, respectively, were included for meta-analysis. The total number of animals tested for AAT was 53,924 with a range of 55-7143 per study, while 12,552 tsetse flies were examined for trypanosomes. To evaluate the risk of bias, a quality assessment checklist was verified with some questions and given a score based on a scale of 0,1 and 2 for no, yes and unclear, respectively.

\section{Statistical analysis}

A summary of prevalence estimates was obtained using fixed and random effects models which were determined by the level of inconsistency/heterogeneity $\mathrm{I}^{2}$ statistic (inverse variance index). While a fixed model assumes perfect and equal procedures for all studies analysed, the random effects model explains the variation that could possibly occur among studies. The heterogeneity does not depend on chance nor the number of studies examined, with 25,50 and $75 \%$ corresponding to low, moderate and high degree values of heterogeneity, respectively [20]. Heterogeneity was further investigated by arranging the studies based on relevant characteristics. Chi-square analysis was used to compare diagnostic methods used in the studies. Geographical locations (North/South) was a major subgroup analysis considered for both AAT and tsetse infections. Tukey's post-hoc multiple pairwise comparison test of one-way ANOVA was used to compare study years of AAT prevalence reports. The map that shows AAT intensity was developed with qGIS (version 2.8.10). Microsoft Excel was used to manage raw data and calculate the 95\% confidence intervals for descriptive analyses. Meta-analysis was conducted on both trypanosome infected animals and tsetse flies. All analyses were done using MedCalc ${ }^{\circ}$ statistical software and WINPEPI statistic package (UK).

\section{Results}

Meta-analysis of AAT natural infection field-based studies The overall prevalence of AAT in the field studies $(n=74)$ was $16.1 \%$ (95\% CI: 12.3-20.3\%) (Table 1). Point estimates of individual studies are presented graphically in Fig. 2. A significant difference between study heterogeneity was observed $\left(\chi^{2}=11830.2, \mathrm{I}^{2}=99.4,95 \% \mathrm{CI}\right.$ : 99.3-99.4, $P<0$. 001). Sub-group analysis based on factors such as geographical region, type of animal, diagnostic technique and Trypanosoma species involved were further analyzed. Results are presented in Table 1. The prevalence of trypanosomes decreased in the first two decades after control intervention and increased thereafter with no significant difference in five decades (Fig. 3). AAT prevalence differed 


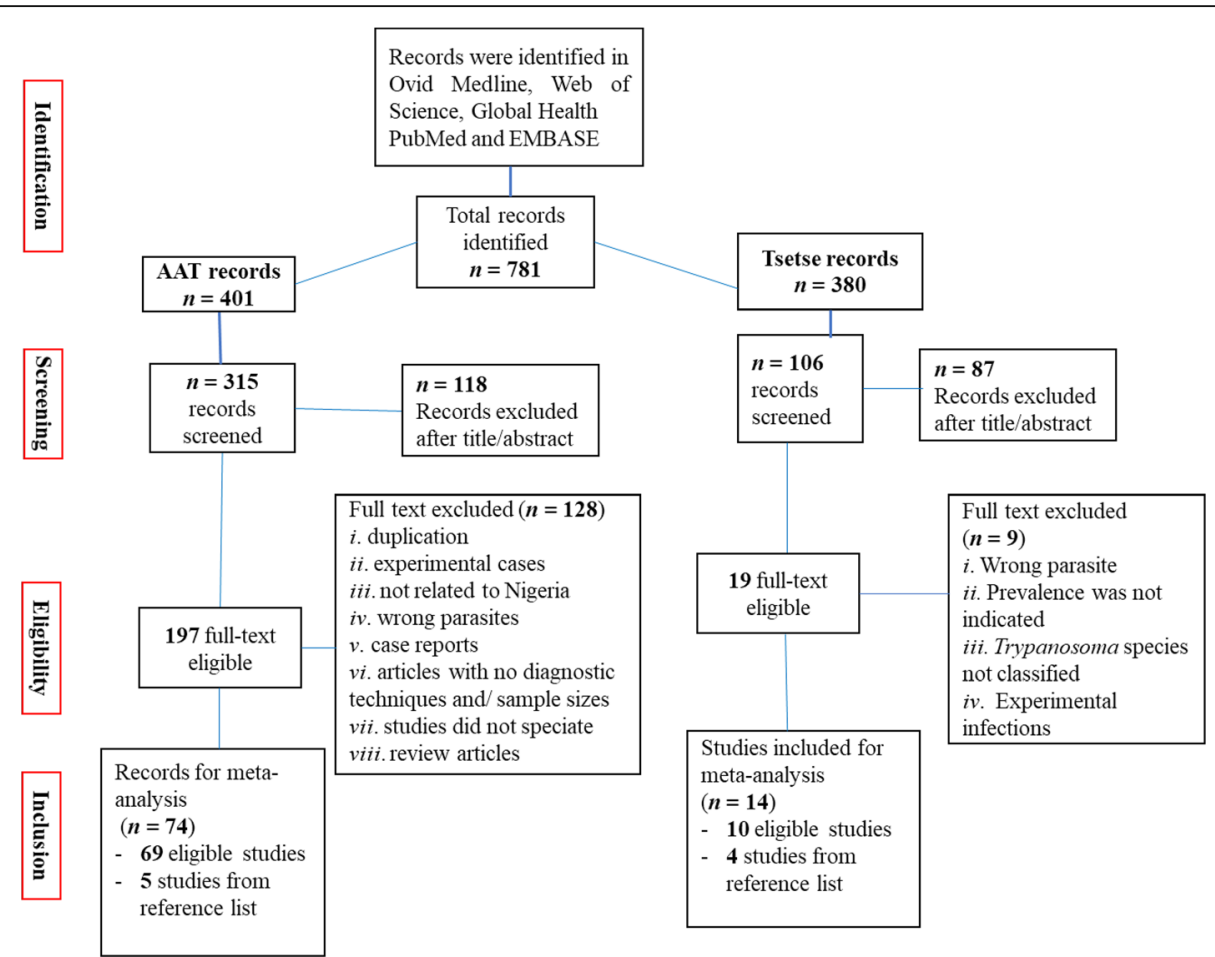

Fig. 1 Flow diagram detailing the selection of eligible studies and excluded studies in a systematic approach for the prevalence of AAT and tsetse infections in Nigeria

between regions with higher infection in southern Nigeria $\left(n=24 ; \chi^{2}=2890.4, \mathrm{I}^{2}=99.1,95 \%\right.$ CI: 99.1-99.3, $P<0$. 0001), though more studies have been reported in northern Nigeria $\left(n=54 ; \chi^{2}=8311.1, \mathrm{I}^{2}=99.4,95 \%\right.$ CI: 99.3-99.4, $P<0.0001)$. Cattle were the most studied animals $(n=55)$ with an overall prevalence of $17.0 \%(95 \%$ CI: $12.3-22.2 \%, \chi^{2}=9383.3, d f=54, \mathrm{I}^{2}=99.4, P<0.0001$ ), while the prevalence based on diagnostic technique revealed $13.0 \%, 21.0$ and $25.5 \%$ for microscopy, serology and PCR methods, respectively. The analyzed results showed varying Trypanosoma species based on diagnostic techniques used for bovine trypanosomiasis. Microscopy showed higher prevalence $T$. vivax, while serology and PCR revealed a higher $T$. congolense (Table 1 ). The analysis of goat trypanosomiasis revealed more studies were carried out using microscopy. Caprine trypanosomiasis prevalence was $3.7 \%(n=14)$ and $71.7 \%(n=1)$ for microscopy and PCR, respectively. All studies on ovine trypanosomiasis were conducted using microscopy and demonstrated a prevalence of $7.7 \%$ (95\% CI: $3.3-13.7 \%, \chi^{2}=453.1, d f=12$, $\left.\mathrm{I}^{2}=97.4 \%, P<0.0001\right)$ with $T$. vivax as most prevalent compared to the other species (Table 1). The prevalence of porcine trypanosomiasis observed was 3.2\% (95\% CI: 1.5-6. 8\%), $27.0 \%$ (95\% CI: $21.2-33.7 \%$ ) and 16.6\% (95\% CI: 14.0 19.5\%) using microscopy, serology and PCR techniques, respectively. Reports on horses and camels are scarce, hence only one study each was retrieved and examined with prevalence of $1.7 \%$ (95\% CI: $0.6-4.2 \%$ ) and 31.5\% (95\% CI: $25.5-38.2 \%)$, respectively. Analyses of data in relation to decadal disease prevalence was used to understand the trend of AAT in Nigeria is shown graphically (Fig. 3).

\section{Meta-analysis of tsetse trypanosome infection field-based studies}

The overall prevalence of trypanosomes in tsetse flies captured in the field $(n=14)$ was $17.3 \%$ (95\% CI: $4.5-$ $36.0 \%$ ) (Table 2). Point estimates of individual studies are presented graphically in Fig. 4. Significant prevalence heterogeneity was observed in the studies $\left(\chi^{2}=6287.8\right.$, $\left.d f=13, \mathrm{I}^{2}=99.8,95 \% \mathrm{CI}: 99.8-99.9, P<0.0001\right)$. The prevalence of trypanosomes in tsetse is significantly higher in the southern compared to northern Nigeria. There were significant $\left(F_{(2,18)}=10.4, P=0.01\right)$ differences in the levels of trypanosome infection between tsetse species. The prevalence of trypanosomes was highest in G. morsitans followed by G. tachinoides and G. palpalis (Table 2). Dissection under the microscope was the most frequent diagnostic technique with only few studies using PCR (Table 2). Trypanosoma vivax was mostly detected, followed by $T$. congolense and $T$. brucei in the tsetse species reported. No heterogeneity of prevalence was observed in T. brucei of Glossina morsitans $\left(\chi^{2}=6.6, d f=4, \mathrm{I}^{2}=39.4 \%, 95 \% \mathrm{CI}\right.$ : $0.0-77.6 \%, P=0.1586)$. 
Table 1 Amalgamated national (Nigeria) AAT prevalence 1960-2017

\begin{tabular}{|c|c|c|c|c|c|}
\hline Attribute & $\begin{array}{l}\text { No. of studies examined/ } \\
\text { total samples examined }\end{array}$ & $\begin{array}{l}\text { Prevalence } \\
(95 \% \mathrm{Cl})(\%)\end{array}$ & $\begin{array}{l}\text { Measure of heterogeneity } \\
\text { (Cochran's Q) }\end{array}$ & $\begin{array}{l}\text { \% Variation; } I^{2} \\
(95 \% \mathrm{Cl})\end{array}$ & $P$-value \\
\hline National & $74(53,924)$ & $16.1(12.3-20.3)$ & 11830.19 & $99.4(99.3-99.4)$ & $P<0.0001$ \\
\hline Northern region & $54(32,134)$ & $15.9(11.1-21.4)$ & 8311.08 & $99.4(99.3-99.4)$ & $P<0.0001$ \\
\hline Southern region & $24(22,055)$ & $19.9(14.0-26.5)$ & 2890.36 & $99.2(99.1-99.3)$ & $P<0.0001$ \\
\hline Cattle & $55(40,863)$ & $17.0(12.3-22.2)$ & 9383.29 & $99.4(99.4-99.5)$ & $P<0.0001$ \\
\hline Microscopy & $45(31,135)$ & $13.0(10.0-16.2)$ & 2749.86 & 98.4 (98.2-98.6) & $P<0.0001$ \\
\hline T. vivax & $32(16,942)$ & $8.2(5.7-11.1)$ & 1183.98 & $97.4(96.9-97.8)$ & $P<0.0001$ \\
\hline T. congolense & $32(16,942)$ & $2.8(1.7-4.3)$ & 725.89 & $95.7(94.8-96.5)$ & $P<0.0001$ \\
\hline T. brucei & $32(16,942)$ & $1.7(0.7-3.1)$ & 1076.37 & $97.1(96.6-97.6)$ & $P<0.0001$ \\
\hline Serology & $2(1175)$ & $21.0(17.9-24.4)$ & 1.57 & $36.4(0.0-0.0)$ & $P<0.0001$ \\
\hline T. vivax & $2(1175)$ & $7.1(5.7-8.7)$ & 0.20 & $0.0(0.0-0.0)$ & $P=0.67$ \\
\hline T. congolense & $2(1175)$ & $9.0(7.4-10.7)$ & 0.34 & $0.0(0.0-0.0)$ & $P=0.60$ \\
\hline T. brucei & $2(1175)$ & $2.0(0.7-4.1)$ & 3.23 & $69.0(0.0-93)$ & $P=0.07$ \\
\hline PCR & 7 (8672) & $25.5(10.5-44.4)$ & 793.26 & $99.2(99.0-99.4)$ & $P<0.0001$ \\
\hline T. vivax & $5(8022)$ & $9.5(2.1-21.2)$ & 231.15 & 98.3 (97.4-98.9) & $P<0.0001$ \\
\hline T. congolense & $3(7754)$ & $25.1(16.7-34.4)$ & 37.26 & $94.6(87.9-97.7)$ & $P<0.0001$ \\
\hline T. brucei & $6(8522)$ & $4.5(2.3-7.4)$ & 56.50 & $91.2(83.5-95.3)$ & $P<0.0001$ \\
\hline Goats & 15 (6270) & & & & \\
\hline Microscopy & $14(6065)$ & $3.7(2.2-5.5)$ & 143.92 & $91.0(86.6-93.9)$ & $P<0.0001$ \\
\hline T. vivax & $12(5783)$ & $1.3(0.6-2.2)$ & 84.21 & 86.9 (78.9-91.9) & $P<0.0001$ \\
\hline T. congolense & $12(5783)$ & $0.74(0.3-1.3)$ & 50.70 & $78.3(62.6-87.4)$ & $P<0.0001$ \\
\hline T. brucei & $12(5783)$ & $0.59(0.1-1.4)$ & 94.37 & $88.3(81.5-92.6)$ & $P<0.0001$ \\
\hline PCR & $1(205)$ & $71.7(65.2-77.4)$ & - & - & - \\
\hline T. vivax & $1(205)$ & $71.7(65.2-77.4)$ & - & - & - \\
\hline Sheep & $13(4089)$ & $7.7(3.3-13.7)$ & 453.06 & $97.4(96.5-98.0)$ & $P<0.0001$ \\
\hline Microscopy & $13(4089)$ & $7.7(3.3-13.7)$ & 453.06 & $97.4(96.5-98.0)$ & $P<0.0001$ \\
\hline T. vivax & 8 (2699) & $2.6(0.3-7.0)$ & 198.47 & 96.5 (94.7-97.6) & $P<0.0001$ \\
\hline T. congolense & 8 (2699) & $2.4(0.7-5.1)$ & 92.80 & $92.5(87.5-95.5)$ & $P<0.0001$ \\
\hline T. brucei & 8 (2699) & $1.1(0.2-2.9)$ & 74.50 & $90.6(83.9-94.5)$ & $P<0.0001$ \\
\hline Pig & $2(900)$ & & & & \\
\hline Microscopy & $1(189)$ & $3.2(1.5-6.8)$ & - & - & - \\
\hline T. brucei & $1(189)$ & $3.2(1.5-6.8)$ & - & - & - \\
\hline Serology & $1(189)$ & $27.0(21.2-33.7)$ & - & - & - \\
\hline T. brucei & $1(189)$ & $27.0(21.2-33.7)$ & - & - & - \\
\hline PCR & $1(712)$ & $16.6(14.0-19.5)$ & - & - & - \\
\hline T. congolense & $1(712)$ & $4.6(3.3-6.4)$ & - & - & - \\
\hline T. brucei & $1(712)$ & $8.9(7.0-11.2)$ & - & - & - \\
\hline Horse & $1(243)$ & $1.7(0.6-4.2)$ & - & - & - \\
\hline Camel & $1(200)$ & $31.5(25.5-38.2)$ & - & - & - \\
\hline
\end{tabular}

Abbreviations: $\mathrm{Cl}$ confidence interval, I inconsistency or variation

\section{Discussion}

National AAT prevalence over the period 1960-2017

African animal trypanosomiasis (AAT) is a major threat to the livestock industry in Nigeria. The national prevalence of the disease is not known. The country has been involved in different elimination programmes of the disease since its first outbreak [21], and the PATTECinitiative was also launched in 2001 [22]. To our knowledge, this is the first national report on the overall prevalence of AAT and trypanosome infected-tsetse flies 


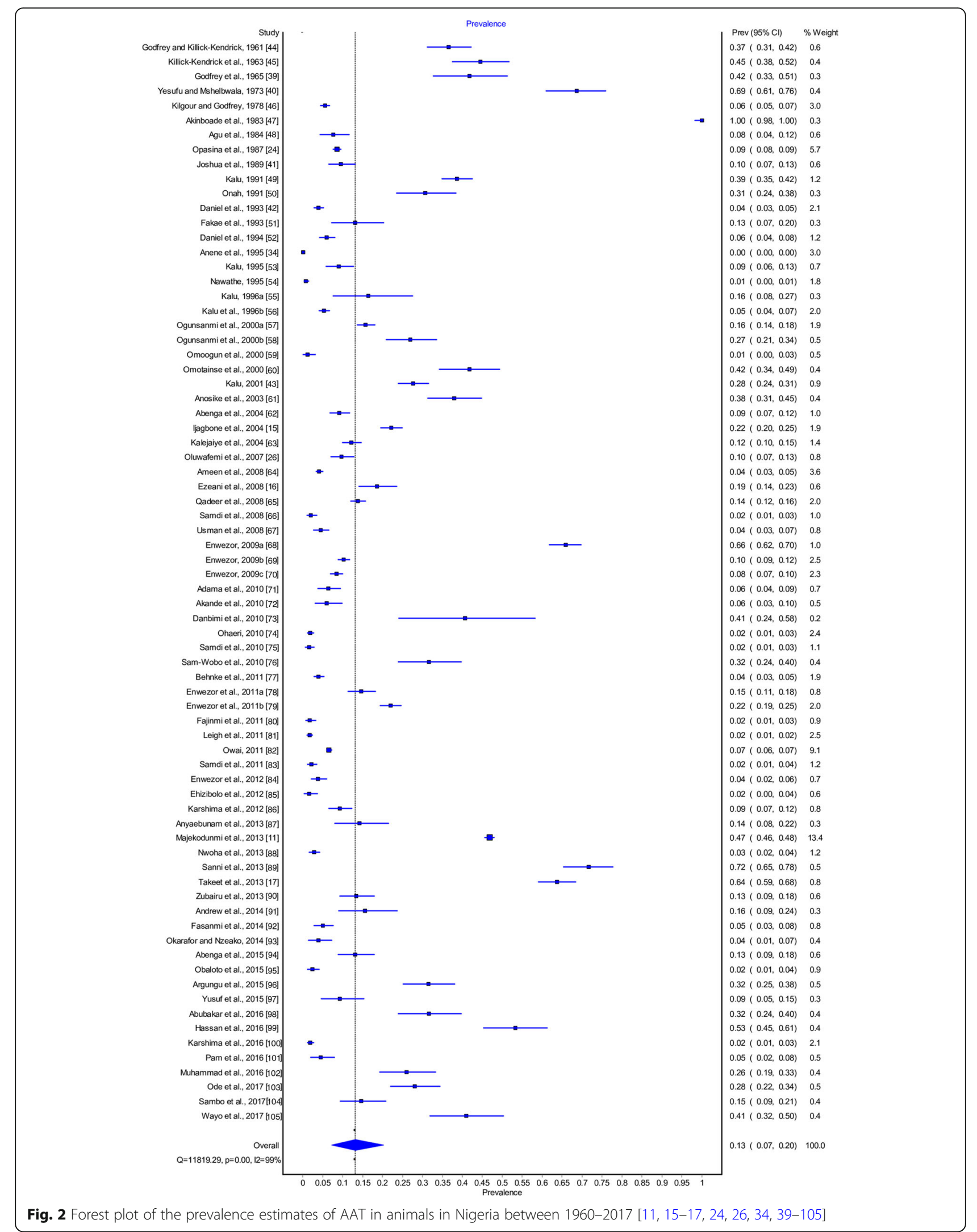




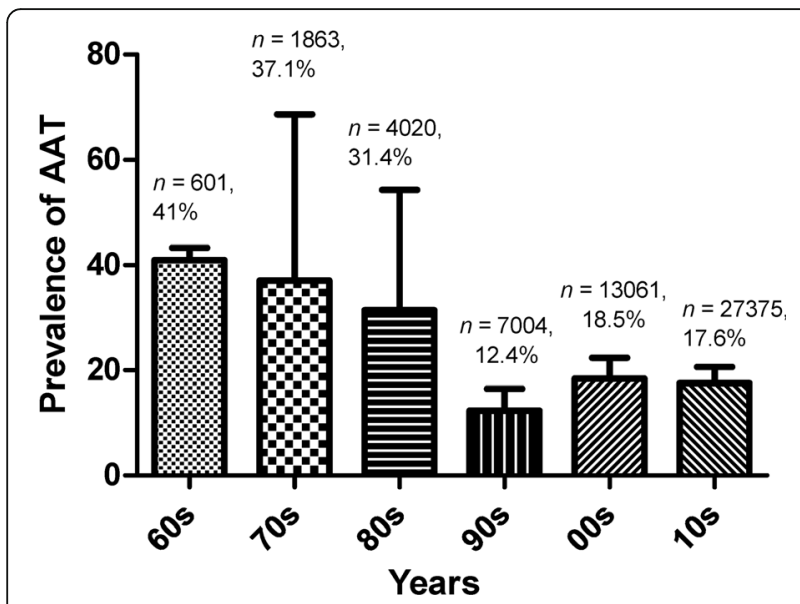

Fig. 3 The prevalence of AAT in Nigeria over six decades. Tukey multiple pairwise comparison test of the analysis of variance shows no significant difference $\left(F_{(5,68)}=1.616, P=0.1676, r^{2}=10.6 \%\right)$ in the prevalence reports across decades. Proportions of each study conducted (74 studies) and total number of animal screened is shown in the graph

after Nigeria gained independence in 1960. In order to understand the epidemiology of AAT, all studies on AAT were analyzed. The high prevalence of AAT observed in this study indicates that the disease is far from been eliminated. While it has been estimated that the presence of AAT reduces the total number of livestock in an area by $25-50 \%$, it has also been predicted that with an elasticity of 0.2 , AAT can reduce the agricultural gross domestic product (GDP) by $5-10 \%$ [18]. This study suggests an increasing trend of AAT in Nigeria and incidentally, well studied and moderately studied states for AAT have veterinary schools (Fig. 5).
Regional (southern vs northern) AAT prevalence over the period 1960-2017

The prevalence of AAT observed in both regions showed no significant difference (Table 1), even though more studies were carried out in northern compared to the southern Nigeria with slightly higher prevalence of pooled estimates (Table 1). Most of the cases observed in the northern regions could be due to a substantial number of cattle herds in the region and transhumance activities [11]. Cattle in southern Nigeria are exposed to an abundance of tsetse flies; however, there is a significant amount of pasture and continuous treatment using chemotherapy. The prevalence in northern and southern regions showed that approximately all regions are at risk of infection (Table 1). Studies showed general reduction in AAT prevalence after control programmes were implemented in northern Nigeria [23] with a corresponding effect in southern Nigeria [24, 25]. However, due to lack of adequate surveillance, monitoring and control of the disease, the prevalence began to rise in northern Nigeria that was thought to be free of the vector [26]. Continuous movements and settlement patterns could be responsible for the increase in the prevalence of AAT in both regions.

\section{National tsetse-trypanosome infection rates over the period 1960-2017}

Tsetse flies are known to be widely distributed across Nigeria [18]. About 196,000 $\mathrm{km}^{2}$ of landmass has been cleared in the northeastern region since 1967 [27] and an additional $1500 \mathrm{~km}^{2}$ in the north-central region in 1987 [28]. However, the presence of trypanosomes

Table 2 Amalgamated national (Nigeria) tsetse trypanosome infection rates 1960-2017

\begin{tabular}{|c|c|c|c|c|c|}
\hline Attribute & $\begin{array}{l}\text { Number of studies examined/ } \\
\text { total samples examined }\end{array}$ & $\begin{array}{l}\text { Prevalence } \\
(95 \% \text { CI) (\%) }\end{array}$ & $\begin{array}{l}\text { Measure of heterogeneity } \\
\text { (Cochran's Q) }\end{array}$ & $\begin{array}{l}\text { \% Variation; } I^{2} \\
(95 \% \mathrm{Cl})\end{array}$ & $P$-value \\
\hline National & $14(12,552)$ & $17.3(4.5-36.0)$ & 6287.77 & 99.8 (99.8-99.9) & $P<0.0001$ \\
\hline Northern region & 9 (3107) & $10.5(5.1-17.5)$ & 244.70 & 96.7 (95.3-97.7) & $P<0.0001$ \\
\hline Southern region & 5 (9445) & $30.4(0.6-78.6)$ & 487.95 & 99.9 (99.9-100) & $P<0.0001$ \\
\hline G. morsitans & $5(4883)$ & $49.7(30.7-68.8)$ & 310.55 & 98.7 (98.1-99.1) & $P<0.0001$ \\
\hline T. vivax & $5(4883)$ & $36.8(21.9-53.2)$ & 221.35 & $98.2(97.2-98.8)$ & $P<0.0001$ \\
\hline T. congolense & $5(4883)$ & $5.9(2.6-10.3)$ & 52.02 & $92.3(85.0-96.1)$ & $P<0.0001$ \\
\hline T. brucei & $5(4883)$ & $0.2(0.0-5.2)$ & 6.60 & $39.4(0.0-77.6)$ & $P=0.1586$ \\
\hline G. tachinoides & 11 (5793) & $11.5(6.1-18.5)$ & 226.36 & 95.1 (93.1-96.6) & $P<0.0001$ \\
\hline T. vivax & $10(5646)$ & $4.9(1.0-11.4)$ & 263.30 & 96.6 (95.1-97.6) & $P<0.0001$ \\
\hline T. congolense & $10(5646)$ & $2.0(0.5-4.5)$ & 85.57 & 89.5 (82.8-93.6) & $P<0.0001$ \\
\hline T. brucei & $10(5646)$ & $1.2(0.2-3.2)$ & 77.30 & $88.4(80.7-93.0)$ & $P<0.0001$ \\
\hline G. palpalis & $11(1874)$ & $4.5(1.6-8.8)$ & 118.42 & 91.6 (86.9-94.6) & $P<0.0001$ \\
\hline T. vivax & $6(1610)$ & $1.6(0.3-3.9)$ & 38.80 & 87.1 (74.3-93.6) & $P<0.0001$ \\
\hline T. congolense & $5(1546)$ & $1.5(0.0-5.2)$ & 69.91 & $94.3(89.5-96.9)$ & $P<0.0001$ \\
\hline T. brucei & $5(1546)$ & $1.2(0.0-5.2)$ & 87.37 & 95.4 (91.9-97.4) & $P<0.0001$ \\
\hline
\end{tabular}




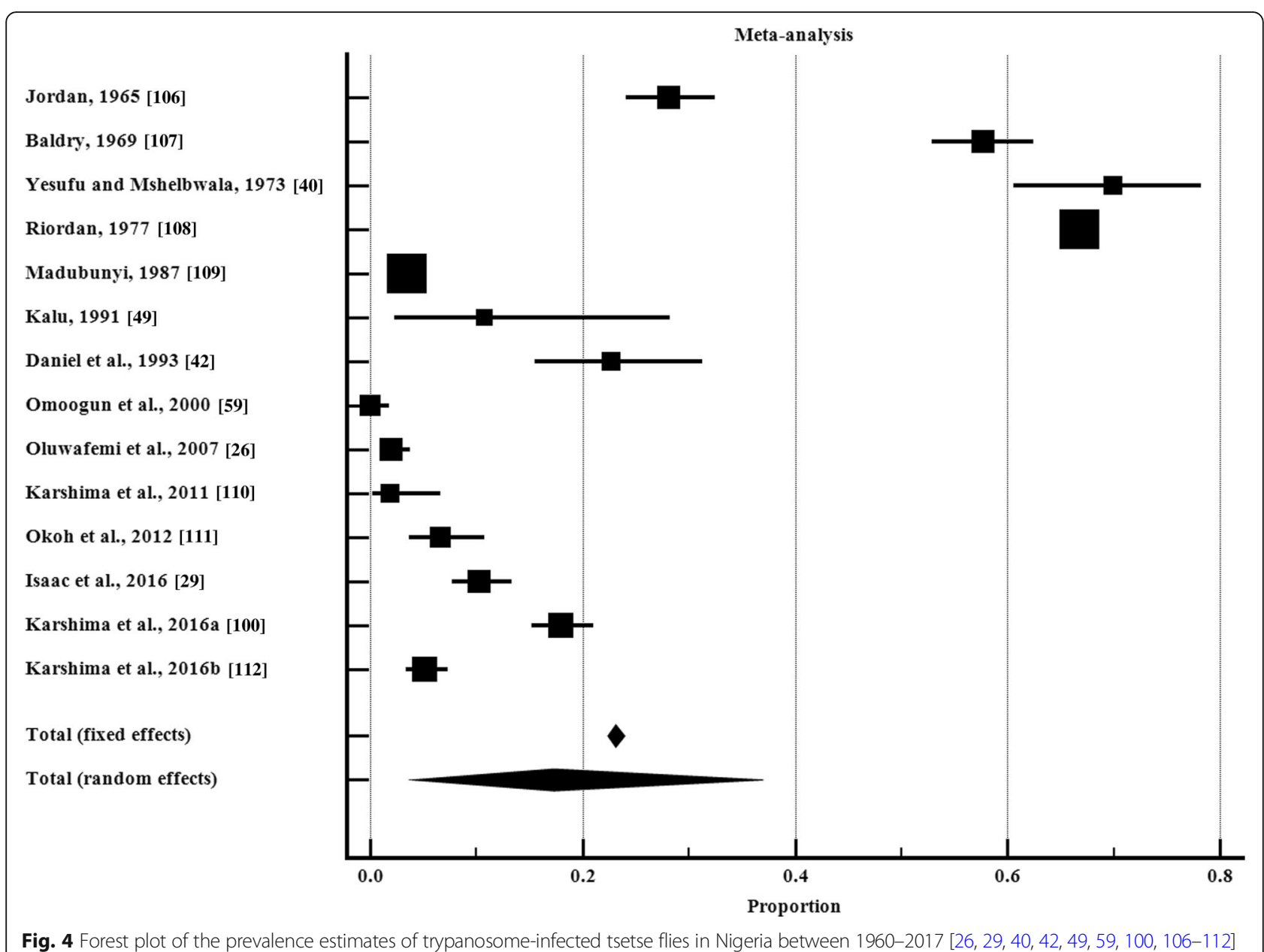

found in tsetse flies sampled from this cleared region in 2007 is significant in assessing the re-emergence of the infected flies [26]. A substantial heterogeneity existed among studies in northern and southern Nigeria (Table 2), even though the southern region is regarded as the "fly belt" zone, because of the favorable environmental condition for tsetse species. No study has compared tsetse infection in both regions as was done for AAT. It was observed that G. tachinoides have been mostly examined followed by $G$. morsitans and G. palpalis. The highest infection rate was observed in G. morsitans even though most of the flies were sampled before the new millennium. The collection of tsetse flies from year 2000 shows that the Palpalis group was mostly present compared to the Morsitans group. This could be due to human activities. The low prevalence trypanosomes observed in G. palpalis and G. tachinoides could be associated to the diagnostic technique (microscopy) used for detecting infection. Recently, PCR analysis has been used to detect trypanosomes in tsetse flies with a high presence of trypanosome DNA [29].
Sub-group (goats, sheep, cattle and pigs) AAT prevalence over the period 1960-2017

Bovine trypanosomiasis has often been targeted because of the increased number of nomads and corresponding number of cattle in the country to meet the protein demand. Studies undertaken on cattle based on diagnostic technique, showed varied results for microscopy, serology and PCR methods (Table 1). This could have affected the disease perception at some point. Small ruminants such as sheep and goats have often been neglected in the integrated control approach because effort on trypanosome control has been concentrated on cattle. However, from this analytical study, the pooled prevalence suggests they could be of great interest in maintaining AAT in mixed herds (large and small ruminants). The low prevalence in small ruminants compared to cattle could be because most breeds of small ruminants in Nigeria such as Sahel/Desert/West African long-legged, West African dwarf and Sokoto goats [30] and Uda, West African dwarf, Balami and Yankasa sheep [31], are trypanotolerant. However, with the presence of 


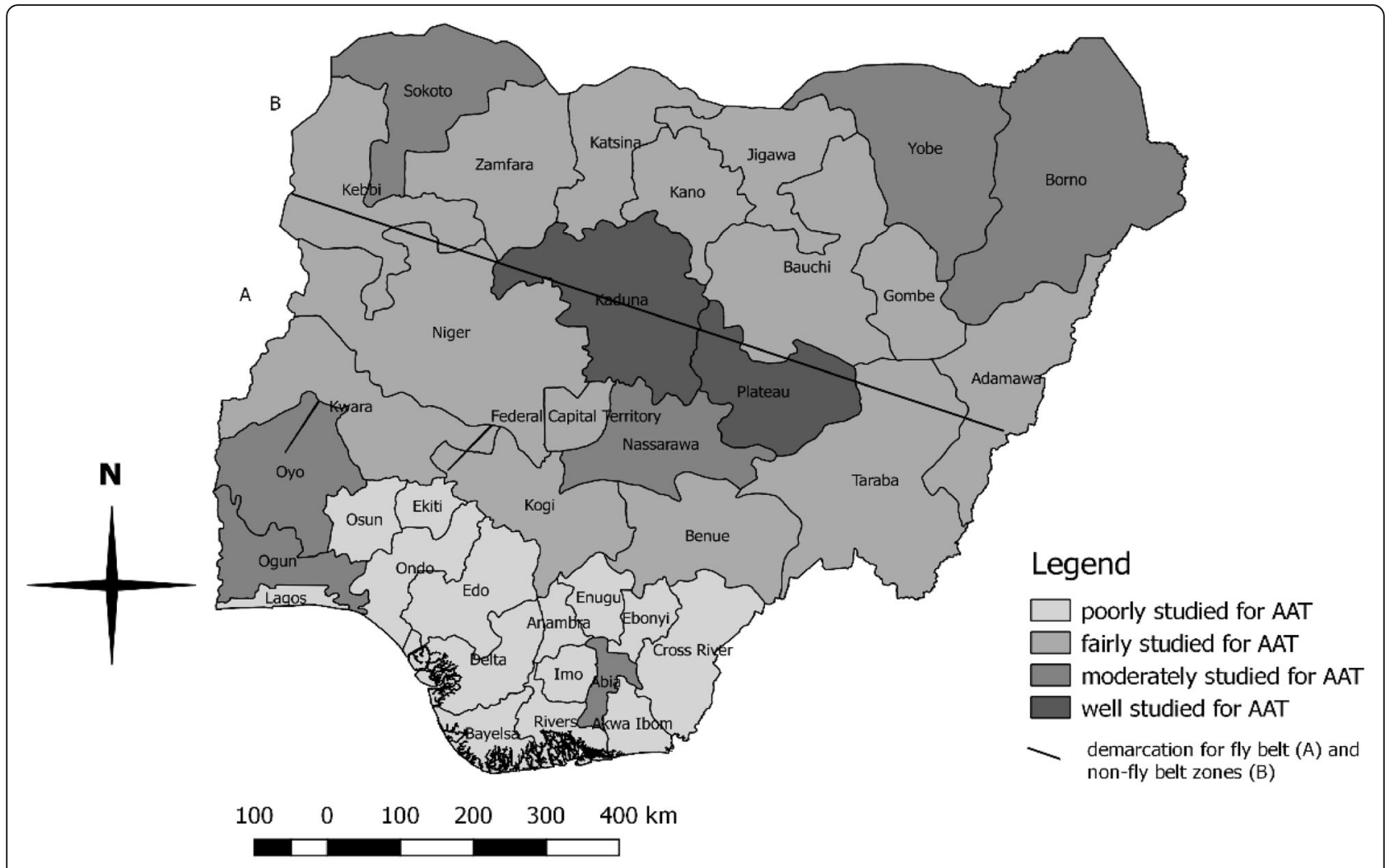

Fig. 5 Nigeria states showing the intensity of trypanosomiasis studies conducted between 1960-2017

trypanosomes in some of these breeds, it is necessary to consider the role of trypanotolerant small ruminants in the epidemiology of AAT. Porcine trypanosomiasis is also economically important especially with the recent detection of $T$. brucei gambiense in pigs from other countries [32, 33]. In Nigeria however, species observed were $T$. b. brucei, and T. congolense (Forest and Savannah). There is a dearth of information in the role of infected pigs in the epidemiology of the AAT in Nigeria. More studies are needed to determine possible transmission of trypanosomes from pigs to other animals and humans in Nigeria. The prevalence of trypanosomiasis in equines and camels suggest that more studies are needed to establish its overall prevalence.

AAT prevalence heterogeneity over the period 1960-2017 The high heterogeneity index observed in livestock (Table 1) is suggestive of potential variations, which could be due to the characteristics of the type of animal sampled (e.g. sedentary, abattoir, market or institutional livestock), geographical regions, seasons of survey or diagnostic techniques used. From the meta-analysis, differences in prevalence exist in animals examined according to year and location of study. Most of the evaluated data from original studies did not investigate some variables such as status of animal while sampling, type of breed, tsetse-host contact, type of management practice and intervention factors, which could be used to identify the actual risk factors responsible for the infection in those animals. However, the prevalence of trypanosomes in tsetse flies which ensures continuous transmission could explain the increasing infection in animals. This persistence could even be sustained by mechanical vectors in the absence or presence of few tsetse flies $[9,34]$. Hence, the prevalence variability is expected from the reports.

\section{AAT prevalence variability over the period 1960-2017: diagnostic techniques and prevalence estimates as a measure of variability and heterogeneity}

Analysis shows that prevalence of AAT reduced from 1960s to 1990s (Fig. 3), this was due to a concerted government effort to oust tsetse flies the biological transmitting vector. Intense aerial spraying of DDT and dieldrin in northeastern Nigeria was reported to have occurred in 1967 because of the high incidence of the disease [28]. Between 1979 and 1987, there was BICOT project [26], which intensified elimination of tsetse flies in Lafia, Nasarawa State, hence a low prevalence was observed in 1990s (Fig. 3). However, an increase in AAT prevalence in the 2000s and 2010s, (Fig. 3), suggests the persistence of the disease despite the government's efforts in the past. 
Varying AAT prevalence was observed due to differences in methods of detection and identification of trypanosome species in Nigeria. Commonly observed methods were light microscopy, enzyme linked immunosorbent assay (ELISA) and polymerase chain reaction (PCR). Heterogeneity based on diagnostic technique showed that PCR was the most sensitive compared to serology and microscopy in all animals except pigs where serology was most sensitive. This could be due to the limited number of studies on porcine trypanosomiasis in Nigeria. The analysis in this study suggests that PCR is more sensitive than the other methods for AAT detection as observed in previous studies [14, 35].

There has been a great deal of debate on the prevailing Trypanosoma species. It was observed from this study that Trypanosoma vivax was mostly reported for studies examined with microscopy while those studied using serology and PCR methods revealed higher prevalence for $T$. congolense. It could be that $T$. vivax was seemingly recognizable or confused with other species under the microscope. The availability of internal transcribed spacer (ITS 1) primers that detects nuclear sequence gene makes identification of a wide range of Trypanosoma species possible [36]. Trypanosoma brucei maintained the lowest infection in cattle using the three techniques (Table 1). The commonly used primers for T. brucei in animals is TBR [37], while there has been argument on its sensitivity when compared to ITS1, and the later does not separate the Trypanozoon group which gives results for T. brucei, T. evansi and T. equiperdum.

Trypanosome prevalence in animals could be affected by several factors such as availability of reservoir hosts, seasonal factors, altitude, fly density and behavior, sensitivity of diagnostic technique, stage of infection, method of sampling, conflict and other human activities [11, 17, 38]. For instance, the microscopy techniques used by different authors varies, while wet mount, thin and thick smear was well-appreciated in the 1960s and 1970s [39, 40], more sensitive methods such as buffy coat technique, haematocrit centrifugation technique, sub-inoculation and standard trypanosome detection method were used in the 1980s, 1990s and 2000s onwards [41, 42, 43]. There have been arguments on the prevalence of $T$. vivax in dry and early wet seasons in Nigeria, while T. congolense have been detected more in the wet season [11]. Several reports in Nigeria have failed to specify the season of sampling in their methodology and this has made it difficult to classify seasonal reports as a measure of variability.

\section{Conclusions}

The high prevalence of AAT and tsetse infection indicates that Nigeria may not eliminate trypanosomiasis any time soon if deliberate efforts are not employed. Microscopy has been widely used to investigate AAT and tsetse infection prevalence in Nigeria; however, the use of PCR could give a higher prevalence due to its sensitivity. Study methodology and risk factor assessment is necessary to validate research output. Further investigation is warranted on how this variation can be explained through risk factor assessment for AAT and tsetse infection.

\section{Additional file}

Additional file 1: Table S1. PRISMA checklist. (DOCX $13 \mathrm{~kb}$ )

\section{Acknowledgements}

We appreciate the University of Edinburgh Library for the use of the database. Many thanks to the Department of Veterinary Parasitology, University of Ibadan where the original work that forms the basis of this article originates.

\section{Funding}

$\mathrm{POO}$ is a Commonwealth scholar, funded by the UK government with reference number NGCN-2016-196.

Availability of data and materials

The datasets used and/or analyzed during this study are included in this published article.

\section{Authors' contributions}

PO compiled, analyzed and interpreted the data regarding AAT and trypanosome-infected tsetse prevalence in Nigeria. 10 was a major contributor in writing the manuscript and cross-checking the analysis. Both authors read and approved the final manuscript.

\section{Ethics approval}

The study was conducted with the permission of the University of Ibadan Animal Ethics Committee (UI-ACUREC/App/12/2016/05) and in line with the guidelines of the committee.

Consent for publication

Not applicable.

\section{Competing interests}

The authors declare that they have no competing interests.

\section{Publisher's Note}

Springer Nature remains neutral with regard to jurisdictional claims in published maps and institutional affiliations.

\section{Author details}

${ }^{1}$ Department of Veterinary Parasitology, Faculty of Veterinary Medicine, University of Ibadan, Ibadan, Nigeria. '2Division of Infection and Pathway Medicine, Deanery of Biomedical Sciences, University of Edinburgh, Edinburgh EH8 9JZ, UK.

Received: 3 November 2017 Accepted: 19 March 2018

Published online: 02 May 2018

\section{References}

1. Swallow BM. Impacts of trypanosomiasis on African agriculture. In: PAAT Technical and Scientific Series 2, PAAT Information Service Publication. Rome: FAO; 2000. p. 52.

2. Diall O, Cecchi G, Wanda G, Argiles-Herrero R, Vreysen MJB, Cattoli G, et al. Developing a progressive control pathway for African animal trypanosomosis. Trends Parasitol. 2017;33:499-509.

3. Reichard RE. Area-wide biological control of disease vectors and agents affecting wildlife. Rev Sci Tech. 2002;21:179-85

4. Peacock L, Cook S, Ferris V, Bailey M, Gibson W. The life cycle of Trypanosoma (Nannomonas) congolense in the tsetse fly. Parasit Vectors. 2012;5:109. 
5. Vincendeau P, Bouteille B. Immunology and immunopathology of African trypanosomiasis. Ann Acad Brasileira Ciên. 2006;78:645-65.

6. Barry D, Carrington M. Antigenic variation. In: Maudlin I, Holmes PH, Miles MA, editors. The trypanosomiasis. Wallingford: CABI International; 2004. p. 25-37.

7. Anene BM, Chima AB, Jibike Gl, Anika SM. Prevalence of trypanosomiasis in Zebu at Obudu ranch- a tsetse free zone in Nigeria. Prev Vet Med. 1991;10: 257-60.

8. Abenga JN, Enwezor FNC, Lawani FAG, Ezebuiro C, Sule J, David KM. Prevalence of trypanosomiasis in trade cattle at slaughter in Kaduna, Nigeria. Nig J Parasitol. 2002;23:107-10.

9. Abdi RD, Agga GE, Aregawi WG, Bekana M, Leeuwen TV, Delespaux V, et al. A systematic review and metanalysis of trypanosome prevalence in tsetse flies. BMC Vet Res. 2017;13:100.

10. Adams ER, Hamilton PB, Gibson WC. African trypanosomes: celebrating diversity. Trends Parasitol. 2010;26(7):324-8.

11. Majekodunmi AO, Fajinmi A, Dongkum C, Picozzi K, Thrusfield MV, Welburn SC. A longitudinal survey of African animal trypanosomiasis in domestic cattle on the Jos Plateau, Nigeria: prevalence, distribution and risk factors. Parasit Vectors. 2013;6:239.

12. Office International des Epizooties. Standardized techniques for the diagnosis of tsetse transmitted trypanosomosis. In: Terrestrial Manual. Rome: OIE; 2008.

13. Office International des Epizooties. Trypanosomosis (tsetse-transmitted). In: OIE Terrestial Manual. Rome: OIE; 2013.

14. Takeet MI, Fagbemi BO, De Donato M, Yakubu A, Rodulfo HE, Peters SO, et al. Molecular survey of pathogenic trypanosomes in naturally infected Nigerian Cattle. Res Vet Sci. 2013;94:555-61.

15. ljagbone IF, Esuruoso GO, Agbede SA. Comparative application of antigen detection enzyme-linked immunosorbent assay and buffy coat parasitological technique for diagnosis of bovine trypanosomiasis in Nigeria. Niger Vet J. 2004;25:13-8.

16. Ezeani MC, Okoro H, Anosa VO, Onyenekwe CC, Meludu CE, Azikiwe CC. Immunodiagnosis of bovine trypanosomiasis in Anambra and Imo states, Nigeria, using enzyme linked immunosorbent assay: zoonotic implications to human health. J Vect Borne Dis. 2008;45:292-00.

17. Karshima SN, Lawal IA, Bata SI, Barde IJ, Adamu PV, Salihu A, et al. Animal reservoirs of Trypanosoma brucei gambiense around the old Gboko sleeping sickness focus in Nigeria. J Parasitol Vect Biol. 2016:8:47-54.

18. Isaac C, Ohiolei JA, Ebhodaghe F, Igbinosa IB, Eze AA. Animal African trypanosomiasis in Nigeria: a long way from elimination/eradication. Acta Trop. 2017;176:323-31.

19. Moher D, Liberati A, Tetzlaff J, Altman DG, Group TP. Preferred reporting items for systematic reviews and meta-analyses: the PRISMA statement. Int J Surg. 2010;8:336-41.

20. Higgins JP, Thompson SG. Quantifying heterogeneity in a meta-analysis. Stat Med. 2002;21:1539-58.

21. Putt SNH, Shaw APM. The socio-economic effects of the control of tsetse transmitted trypanosomiasis in Nigeria. Arlinton: Proceedings of the 3rd International Symposium on Veterinary Epidemiology and Economics; 1982.

22. Vreysen MJ, Saleh KM, Ali MY, Abdulla AM, Zhu Z, Juma KG, et al. Glossina austeni (Diptera: Glossinidae) eradicated on the Island of Unguga, Zanzibar, using the sterile insect technique. J Econ Entomol. 2000;93:123-35.

23. Onyiah JA. African animal trypanosomiasis: an overview of current status in Nigeria. Trop Vet. 1997;15:111-6.

24. Opasina BA, Ekwuruke JO. Trypanosomosis in Nigerian trade cattle. Trop Anim Hlth Prod. 1987;19:251-2.

25. Ikede BO, Reynolds L, Ogunsanmi AO, Fawumi MK, Ekwuruke JO, Taiwo VO. The epizootiology of bovine trypanosomiasis in the derived savannah zone of Nigeria: a preliminary report. Lome: 19th Meeting of the International Scientific Council for Trypanosomiasis Research and Control; 1987.

26. Oluwafemi RA, llemobade AA, Laseinde EAO. The impact of African animal trypanosomiasis and tsetse on the livelihood and wellbeing of cattle and their owners in the BICOT study area of Nigeria. Sci Res Essays. 2007;2:380-3.

27. International Livestock Centre for Africa/National Animal Production Research Institute. Livestock systems research in Nigeria's sub-humid zone. In: Proceedings of the second ILCA/NAPRI symposium, 29 October - 2 November 1984, Kaduna, Nigeria. p. 1984.

28. Oladunmade MA, Feldmann U, Takken W, Tenabe SO, Hamann HJ, Onah J, et al. Eradication of Glossina palpalis palpalis (Robineau-Desvoidy) (Diptera: Glossinidae) from agropastoral land in central Nigeria by means of the sterile insect technique. 1990. In: The sterile insect technique for tsetse control or eradication. Nigeria: IAEA Proceedings of a meeting; 1988. p. 5-23.

29. Isaac C, Ciosi M, Hamilton A, Scullion KM, Dede P, Igbinosa IB, et al. Molecular identification of different trypanosome species and subspecies in tsetse flies of northern Nigeria. Parasit Vectors. 2016;9:301.

30. Ngere LO, Adu IF, Okubanjo IO. The indigenous goats of Nigeria. AGRI. 1984;3:1-9.

31. Adu IF, Ngere LO. The indigenous sheep of Nigeria. W Rev Anim Prod. 1979; 15:51-62.

32. Simo G, Asonganyi T, Nkinin SW, Njiokou F, Herder S. High prevalence of Trypanosoma brucei gambiense group 1 in pigs from the Fontem sleeping sickness focus in Cameroon. Vet Parasitol. 2006;139:57-66.

33. Hamill LC, Kaare MT, Welburn SC, Picozzi K. Domestic pigs as potential reservoirs of human and animal trypanosomiasis in northern Tanzania. Parasit Vectors. 2013;6:322.

34. Anene BM, Ezekwe AG. Trypanosomosis in intensively reared Muturu calves in Nigeria. Trop Anim Hlth Prod. 1995;27:229-30.

35. Wastling SL, Welburn SC. Diagnosis of human sleeping sickness: sense and sensitivity. Trends Parasitol. 2011;27:394-402.

36. Njiru ZK, Constantine CC, Guya S, Crowther J, Kiragu JM, Thompson RCA, et al. The use of ITS1 rDNA PCR in detecting African trypanosomes. Parasitol Res. 2005;95:186-92.

37. Katakura K, Lubinga C, Chitambo H, Trada Y. Detection of Trypanosoma congolense and Trypanosoma brucei subspecies in cattle in Zambia by polymerase chain reaction from blood collected on a filter paper. Parasitol Res. 1997;83:241-4.

38. Albert M, Wardrop NA, Atkinson PM, Torr SJ, Welburn SC. Tsetse fly (G. f. fuscipes) distribution in the Lake Victoria Basin of Uganda. PLoS Negl Trop Dis. 2015;9: e00R03705.

39. Godfrey DG, Killick-Kendrick R, Ferguson W. Bovine trypanosomosis in Nigeria. IV. Observations on cattle trekked along a trade-cattle route through areas infested with tsetse fly. Ann Trop Med Parasitol. 1965;59: 255-69.

40. Yesufu HM, Mshelbwala AS. Trypanosomosis survey in cattle and tsetse flies along a trade cattle route in southern Nigeria. Ann Trop Med Parasitol. 1973;67:307-12.

41. Joshua RA, Shanthikutmar S. Naturally occurring trypanosomosis in some cattle herds around the Jos Plateau of Nigeria. Bull Anim Hlth Prod Afr. 1989:37:95-6.

42. Daniel AD, Dadah AJ, Kalejaiye JO, Dalhatu AD. Prevalence of bovine trypanosomosis in Gongola State of northern Nigeria. Rev Elev Med Vet Pays Trop. 1993;46:571-4

43. Kalu AU, Oboegbulem SI, Uzoukwu M. Trypanosomosis in small ruminants maintained by low riverine tsetse population in central Nigeria. Small Rumin Res. 2001;40:109-15.

44. Godfrey DG, Killick-Kendrick R, Ferguson W. Bovine trypanosomiasis in Nigeria. I: The inoculation of blood into rats as a method of survey in the Donga Valley, Benue Province. Ann Trop Med Parisitol. 1961;55:270-6.

45. Killick-Kendrick R, Godfrey DG. Bovine trypanosomosis in Nigeria. II. The incidence among some migrating cattle, with observations on the examination of wet blood preparations as a method of survey. Ann Trop Med Parasitol. 1963;57:117-26.

46. Kilgour V, Godfrey DG. The influence of lorry transport on the Trypanosoma vivax infection rate in Nigerian trade cattle. Trop Anim HIth Prod. 1978;10:145-8.

47. Akinboade OA, Ogunji FO, Dipeolu OO. The incidence of trypanosomosis in the cattle population situated along the peripheries of the Kanji-NationalPark in Nigeria. Zentralbl Veterinarmed B. 1983;30:145-8.

48. Agu WE. Incidence of bovine trypanosomosis in six villages of Kaduna State, Nigeria. In: Proceedings of the National Conference on Diseases of Ruminants, 3-6 October 1984, Vom, Nigeria. p. 1984.

49. Kalu AU. An outbreak of trypanosomosis in Jos Plateau, Nigeria. Bull Anim Hlth Prod Afr. 1991;23:215-6.

50. Onah DN. Porcine trypanosomosis in Nigeria: Infections in local and exotic pigs in the Nsukka area of Anambra State. Trop Anim Hlth Prod. 1991;123:141-6.

51. Fakae BB, Chiejina SN. The prevalence of concurrent trypanosome and gastrointestinal nematode infections in West African dwarf sheep and goats in Nsukka area of eastern Nigeria. Vet Parasitol. 1993:49:313-8.

52. Daniel AD, Joshua RA, Kalejaiye JO, Dada AJ. Prevalence of trypanosomiasis in sheep and goats in a region of northern Nigeria. Rev Elev Med Vet Pays Trop. 1994;47:295-7.

53. Kalu AU. Prevalence of trypanosomosis among trypanotolerant cattle at the lower Benue river area of Nigeria. Prev Vet Med. 1995;24:97-03. 
54. Nawathe DR, Srivastava GC, Basu AK, Kollere MA. Trypanosomosis in small ruminants in the arid zone, Nigeria. Bull Anim HIth Prod Afr. 1995;43:293-4.

55. Kalu AU. Current status of tsetse fly and animal trypanosomosis on the Jos Plateau, Nigeria. Prev Vet Med. 1996a;27:107-13.

56. Kalu AU. Acute trypanosomosis in a sedentary herd on the tsetse free Jos Plateau, Nigeria. Brit Vet J. 1996b;152:477.

57. Ogunsanmi AO, Ikede BO, Akpavie SO. Effects of management, season, vegetation zone and breed on the prevalence of bovine trypanosomiasis in South Western Nigeria. Isr J Vet Med. 2000a;55:1-7.

58. Ogunsanmi A, Taiwo V, Ohore G. Application of antigen detection enzyme immunoassay for diagnosis of porcine Trypanosoma brucei infection. Vet Arhiv. 2000b;70:231-8.

59. Omoogun GA, Akinboade OA. Tsetse and bovine trypanosomosis incidence at Egbe in the derived savanna zone of Nigeria. Insect Sci Appl. 2000;20:215-9.

60. Omotainse SO, Edeghere $\mathrm{H}$, Omoogun GA. The prevalence of animal trypanosomiasis in Konshisha local government area of Benue State, Nigeria. Isr J Vet Med. 2000;55:142-3.

61. Anosike JC, Opara MN, Okoli CG, Kyakya A, Okoli IC. Bovine trypanosomiasis in sedentary cattle at previously assumed-free Jos Plateau, Nigeria. Niger Vet J. 2003;24:33-6.

62. Abenga JN, Enwezor FNG, Lawani FG, Osue HO, Ikemereh ECD. Trypanosome prevalence in cattle in Lere area in Kaduna State, Northcentral Nigeria. Rev Elev Med Vet Pays Trop. 2004;57:45-8.

63. Kalejaiye JO, Omotainse SO, Omoogun GA. Prevalence and distribution of ruminant trypanosomiasis in Bokkos Local Government Area of Plateau State, Nigeria. Afr J Clin Exp Microbiol. 2004;5:222-4.

64. Ameen SA, Joshua RA, Adedeji OS, Raheem AK, Akingbade AA, Leigh OO. Preliminary studies on prevalence of Ruminant trypanosomosis in Ogbomoso area of Oyo State, Nigeria. Middle-East J Sci Res. 2008;3:214-8.

65. Qadeer MA, Danbirni S, Usman M, Akogun OB, Gundiri MA, Bobbo AG. Prevalence of bovine trypanosomosis in Bassa local government area, Plateau State, Nigeria. Nig J Par. 2008;29:136-9.

66. Samdi S, Abenga JN, Fajinmi A, Kalgo A, Idowu T, Lawani F. Seasonal variation in trypanosomosis rates in small ruminants at the Kaduna Abattoir, Nigeria. Afr J Biomed Res. 2008;11:229-32.

67. Usman SB, Babatunde OO, Oladipo KJ, Felix LAG, Gutt BG, Dongkum C. Epidemiological survey of animal trypanosomiasis in Kaltungo local government area, Gombe State, Nigeria. J Protozool Res. 2008;18:96-05.

68. Enwezor FNC, Bossard EG, Esievo KAN, Umoh JU, Zaria LT, Anere Jl. Determination of serological prevalence of animal trypanosomisis in the Kachia grazing reserve by inhibition ELISA. Bull Anim HIth Prod Afr. 2009a; 57:5-11.

69. Enwezor FNC, Shaida S, Omoogun GA, Umoh JU, Esievo KN. Assessment of tsetse situation in the Kachia Grazing Reserve, north-west, Nigeria. Bull Anim Hlth Prod Afr. 2009b;57:369-71.

70. Enwezor FNC, Umoh JU, Esievo KAN, Halid I, Zaria LT, Anere J. Survey of bovine trypanosomosis in the Kachia Grazing Reserve, Kaduna State, Nigeria. Vet Parasitol. 2009;159:121-5.

71. Adama JY, Usman A, Maigida R, Adeyemi RA. Incidence of trypanosomes among white Fulani and Sokoto Gudali breeds of cattle in Niger State, Nigeria Sokoto. J Vet Sci. 2010;8:22-5.

72. Akande FA, Takeet MI, Makanju OA. Haemoparasites of cattle in Abeokuta, south-west Nigeria. Sci World J. 2010;5:19-21.

73. Danbimi S, Okaiyeto SO, Kudi AC, Pewan SB. Bovine trypanosomosis and tuberculosis in a nomadic herd in Sabon Gari local government area of Kaduna State, Nigeria. J Anim Vet Adv. 2010;9:1285-8.

74. Ohaeri CC. Prevalence of trypanosomosis in ruminants in parts of Abia State, Nigeria. J Anim Vet Adv. 2010;9:2422-6.

75. Samdi SM, Fajinmi AO, Kalejaye JO, Wayo B, Haruna MK, Yarnap JE, et al. Periodic variation in Trypanosoma infection rates in trade small ruminants at slaughter in Kaduna Central Abattoir. Res J Vet Sci. 2010;3:189-93.

76. Sam-Wobo SO, Igenezoa AJ, Idowu OA, Otesile EB, Ekpo UF, Kehinde OO. Bovine trypanosomosis and its impact on cattle in derived savanna areas of Ogun State, Nigeria. J Public Health Epidemiol. 2010;1:43-7.

77. Behnke JM, Chiejina SN, Musongong GA, Nnadi PA, Ngongeh LA, Abonyi FO, et al. Resistance and resilience of traditionally managed West African dwarf goats from the savanna zone of northern Nigeria to naturally acquired trypanosome and gastrointestinal nematode infections. J Helminthol. 2011;85: 80-91.

78. Enwezor FNC, David K. Survey of cattle trypanosomosis at certain communities under pastoral resolve area, Kaduna State, Nigeria. Bamako: 31st International
Scientific Council for Trypanosomosis Research and Control (ISCTRC) Conference; 2011.

79. Enwezor FNC, Bello B, Kalgo A, Zaria LT. Improving cattle industry through surveillance and control of trypanosomosis in Kauru area, Kaduna State, Nigeria. Bamako: 31st International Scientific Council for Trypanosomosis Research and Control (ISCTRC) Conference; 2011.

80. Fajinmi AO, Faleke OO, Magaji AA, Daneji Al, Gweba M. Presence of Trypanosome species and determination of anaemia in trade cattle at Sokoto Abattoir, Nigeria. Res J Parasitol. 2011;6:31-42.

81. Leigh OO, Fayemi OE. The prevalence of trypanosomosis in female WAD goats in three local government areas of Ibadan, Nigeria. Global Vet. 2011;6: $11-5$.

82. Owai PU. Prevalence of bovine trypanosomosis in Cross River State, Nigeria. J Food Agric Enviro. 2011;9:452-4.

83. Samdi SM, Fajinmi AO, Kalejaiye JO, Wayo B, Haruna MK, Yarnap JE, et al. Prevalence of trypanosomosis in cattle at slaughter in Kaduna Central Abattoir. As J Anim Sci. 2011:5:162-5.

84. Enwezor FNC, Samdi SM, ljabor O, Abenga JN. The prevalence of bovine trypanosomes in parts of Benue State, north-central Nigeria. J Vect Borne Dis. 2012;49:188-90.

85. Ehizibolo DO, Kamani J, Ehizibolo PO, Egwu KO, Dogo Gl, Salami-Shinaba JO. Prevalence and significance of parasites of horses in some states of northern Nigeria. J Equine Sci. 2012;23:1-4.

86. Karshima SN, Ajogi I, Lawal Al, Mohammed G, Okubanjo OO. Detection of Trypanosoma brucei gambiense specific LiTat 1.3 antibodies in humans and cattle in Taraba State, north-eastern Nigeria. J Vet Adv. 2012;2:580-5.

87. Anyaegbunam LC, Okafor OJ. Trypanosomosis in red sokoto and west African dwarf goats at Ikpa Abattoir, Nsukka, Enugu State, Nigeria. J Ent Zool Stud. 2013;1:35-7

88. Nwoha RIO, Onyeabor A, Igwe KC, Daniel-Igwe G, Onuekwusi GCO, Okah U. Prevalence of haemoparasites in livestock in Ikwuano Local Government Area of Abia State. J Fish Liv Prod. 2013;2:1-3.

89. Sanni TM, Onasanya GB, Adefenwa MA, Yakubu CO, Ikeobi ON, Adebambo OA, et al. Molecular diagnosis of subclinical African Trypanosoma vivax infection and association with physiological indices and serum metabolites in extensively managed goats in the tropics. Open J Vet Med. 2013;3:39-45.

90. Zubairu Al, Midau A, Dazala IU, Yahya MM, Buba ZM. The prevalence of bovine trypanosomosis in song local government area of Adamawa State, Nigeria. Global Vet. 2013;11:310-3.

91. Andrew T, Ibrahim JL, Maikai BV, Baraya K, Daniel J, Timothy T, et al. Prevalence of Trypanosoma species in slaughtered cattle in Jos Abattoir, Plateau State, Nigeria. Int J Sci Appl Res. 2014;1:67-76.

92. Fasanmi OG, Okoroafor UP, Nwufoh OC, Bukola-Oladele OM, Ajibola ES. Survey for trypanosoma species in cattle from three farms in Iddo local government area, Oyo State. Sok J Vet Sci. 2014;12:57-61.

93. Okorafor UP, Nzeako SO. Prevalence of haemoparasites of cattle from three abattoirs in Ibadan metropolis Oyo State, Nigeria. IJSRES. 2014;2:244-9.

94. Abenga JN. Effect of flooding on trypanosome infection rates in trade cattle at central abattoir Makurdi metropolis, Benue State, north-central Nigeria. Ann Res Rev Biol. 2015;8:1-6.

95. Obaloto OB, Shamaki BU, Idehen CO, Eche TA, Balak GG, Dongkum C, et al. Survey of animal trypanosomosis and biting flies in parts of Alkaleri local government area of Bauchi State, Nigeria. J Biol Agr Healthc. 2015;5:16-9.

96. Argungu SY, Bala AY, Liman B. Pattern of Trypanosoma evansi infection among slaughtered camels (Camelus dromedarius) in Sokoto Central Abattoir. J Zool BioSci Res. 2015;2:1-7.

97. Yusuf AB, Abubakar A, Musa UB, Haruna MK, Garba HA, Maigari AK, et al. Surveillance for tsetse and trypanosomosis in Bagudo local government area northwestern Nigeria. IOSR J Agric Vet Sci. 2015;8:43-8.

98. Abubakar A, Sabo HM, Abdulkadir S, Halliru SN, Umar RB, Abdulkadir DA. Epidemiology of trypanosomosis in derived savannah of Nigeria. J Pharm Biol Sci. 2016:11:51-4

99. Hassan DI, Ikeji FN, Musa SI, Yusuf ND, Adua MM, Muhammed MM. Prevalence of bovine trypanosomosis in Lafia Abattoir, Lafia, Nasarawa State, Nigeria. Int J Sci Appl Res. 2016;2:41-7.

100. Karshima SN, Ajogi I, Mohammed G. Eco-epidemiology of porcine trypanosomosis in Karim Lamido, Nigeria: prevalence, seasonal distribution, tsetse density and infection rates. Parasit Vectors. 2016;9:448.

101. Pam VA, Pam DD, Gullek JF, Okoro J, Ogbu Kl, Bot CJ, et al. Prevalence of Trypanosoma species in slaughtered cattle in Jos Abattoir, Plateau State, Nigeria. Int J Sci Appl Res. 2016;1:67-76. 
102. Muhammad AA, Sambo F, Danladi LO, Salawu MJ, Jarmai KY, Abubakar S, et al. Evaluation of microscopy and polymerase chain reaction methods for identification of Trypanosoma vivax in cattle from three selected abattoirs in Kaduna State, Nigeria. Int J Health Sci Res. 2016:6:184-90.

103. Ode S, Adamu M, Taioe M, Thekisoe O, Adamu S, Saror D. Molecular occurence of trypanosomes, erythrocyte and serum sialic acid concentrations of Muturu and Bunaji cattle in Benue State, Nigeria. Vet Parasitol. 2017;242:10-3.

104. Sambo F, Yakubu SE, Ado SA. Diagnosis of Trypanosoma brucei in cattle from three selected abattoirs and three farms in Kaduna State. RJLBPCS. 2017;2:177-86.

105. Wayo B, Samdi SM, Fajinmi AO, Bizi R, Dauda H, Muhammad AA, et al. Prevalence of trypanosomiasis in sheep in the Kachia Grazing Reserve Kachia, Kaduna State, Nigeria. Afr J Clin Exp Microbiol. 2017;18:120-3.

106. Jordan AM. Bovine trypanosomosis in Nigeria. V. The tsetse fly challenge to a herd of cattle trekked along a trade-cattle route. Ann Trop Med Parasitol. 1965;59:270-6.

107. Baldry DAT. Distribution and trypanosome infection rates of Glossina morsitans submorsitans Newst. along a trade cattle route in southwestern Nigeria. Bull Entomol Res. 1969;58:537-48.

108. Riordan K. Long term variations in trypanosome infection rates in highly infected tsetse flies on a cattle route in southwestern Nigeria. Ann Trop Med Parasitol. 1977:71:11-20.

109. Madubunyi LC. Trypanosome infections in Glossina spp. inhabiting peridomestic agroecosystems in Nsukka area, Anambra State, Nigeria. Ann Trop Med Parasitol. 1987;81:319-29.

110. Karshima SN, Ajogi I, Mohammed G, Lawal Al. A survey for biting flies in three local government areas of Taraba State, Nigeria. Sokoto J Vet Sci. 2011;9:36-8.

111. Okoh KE, Anavhe A, Ayakpat HN, Onotu CS, Anchau R, Ajakaiye JJ. Trypanosomes infection in field-captured tsetse flies of the subgenus Nemorhina in southern guinea savanna zone of Nigeria. Curr Res J Biol Sci. 2012:4:713-6.

112. Karshima SN, Lawal IA, Okubanjo OO. Feeding patterns and xenomonitoring of trypanosomes among tsetse flies around the Gashaka-Gumti National Park in Nigeria. J Parasitol Res. 2016; https://doi.org/10.1155/2016/1591037.

\section{Submit your next manuscript to BioMed Central and we will help you at every step:}

- We accept pre-submission inquiries

- Our selector tool helps you to find the most relevant journal

- We provide round the clock customer support

- Convenient online submission

- Thorough peer review

- Inclusion in PubMed and all major indexing services

- Maximum visibility for your research

Submit your manuscript at www.biomedcentral.com/submit 